Conference or Workshop Item (Paper)

Balzter, Heiko; Cuevas-Gonzalez, Maria; Gerard, France; Riano, David. 2008 Post-fire vegetation phenology in Siberian burn scars. In: 2008 IEEE International Geoscience \& Remote Sensing Symposium, Boston, 7-11 July 2008. Institute for Electrical and Electronics Engineers.

This version available at http://nora.nerc.ac.uk/5506/

NERC has developed NORA to enable users to access research outputs wholly or partially funded by NERC. Copyright and other rights for material on this site are retained by the authors and/or other rights owners. Users should read the terms and conditions of use of this material at http://nora.nerc.ac.uk/policies.html\#access 


\section{Post-fire vegetation phenology in Siberian burn scars}

\author{
Heiko Balzter \\ University of Leicester, Department of Geography \\ Leicester, LE1 7RH, UK \\ hb91@le.ac.uk \\ France Gerard \\ Centre for Ecology and Hydrology (CEH) \\ Monks Wood, Cambridgeshire, PE28 2LS, UK \\ ffg@ceh.ac.uk
}

\author{
Maria Cuevas Gonzalez \\ Centre for Ecology and Hydrology (CEH) \\ Monks Wood, Cambridgeshire, PE28 2LS, UK \\ mjgo@ceh.ac.uk \\ David Riaño \\ University of California \\ Center for Spatial Technologies and Remote Sensing \\ One Shields Avenue, Davis, CA, USA, 95616-8617 \\ driano@ucdavis.edu
}

\begin{abstract}
Boreal forests comprise one third of global forested area and are the largest terrestrial carbon store. Forest fires are the regions most dynamic disturbance factor, occurring mainly in Siberia, Russian Far East, Canada and Alaska, and these fires represent a globally important release of terrestrial carbon to the atmosphere, via the burning of vegetation and organic soils. Currently the boreal region is believed to be a net carbon sink, but climate change predictions indicate significant boreal warming, with consequent increases in fire activity and carbon release. Ultimately, the boreal zone may become a net carbon source through forest fires and increased soil decomposition, and there is evidence that the Canadian forest may have already made this transition.

Critical to estimating both direct and longer-term fire-related perturbations to boreal carbon storage is knowledge of fire extent, intensity and/or type, which has a strong control on forest fire "damage", the fraction of available fuel combusted, and patterns of post-fire re-growth. These variables are currently derived from model-based assessment of often-uncertain accuracy, introducing large uncertainties to current carbon flux calculations.

The post-fire re-growth process is of great importance since whilst fire releases carbon into the atmosphere, carbon sequestration through post-fire regeneration of plants and woody vegetation may help to reduce the amounts of carbon in the atmosphere. Observational data, such as vegetation indices, biophysical vegetation parameters, burnt area and fire radiative power, derived from satellite measurements are exploited to investigate post-fire regeneration and pre and post-fire temporal dynamics in the boreal forest. The relationship between post-fire dynamics and variables such as fire intensity, vegetation cover and climate are investigated.

The ultimate aim of the proposed work is to improve insight into the Siberian boreal forest post-fire dynamics, leading to more realistic carbon flux quantification in the boreal biome and subsequently to a better quantitative understanding of the role of boreal forest regeneration in the global atmospheric carbon record.
\end{abstract}

Keywords: Phenology, fire, climate change, Siberia, forest.

\section{INTRODUCTION}

One third of the global forested area is covered by boreal forest. The boreal forest contains $\sim 49 \%$ of the total carbon pool in forested ecosystems (Dixon et al., 1994), or about $37 \%$ of the total global terrestrial carbon pool (plant biomass and soil carbon) (Goldammer and Stocks, 2000). Forest fires are a dynamic disturbance factor and can dominate boreal ecosystem dynamics, by creating a landscape composed of patches of regenerating forest in different stages of succession, with specific patterns of biogeochemical cycling and carbon sequestration. In Russian forests, which account for $70 \%$ of Earth's boreal forest, an estimated $40-96 \%$ of total forested area is in some phase of post-fire succession (Rojkov et al., 1996). Boreal forest fires represent a globally important source of carbon to the atmosphere. Currently the boreal region is believed by many to be a net carbon sink, but climate change model scenarios indicate that the circumpolar regions will warm much faster than global average temperatures, with consequent likely increases in fire activity and carbon release.

One of the key steps to estimate the future contribution of boreal forests to the global carbon cycle is quantification of the role fire recovery plays in stand level carbon dynamics (Harden et al., 2000; Trumbore and Harden, 1997). Moreover, stand age is critical to understanding the carbon balance of boreal forests on a regional basis (Litvak et al., 2003). Russia alone contains about two-thirds of the world's boreal forest, and most of it is present in Siberia. A better understanding of post-fire succession in the Siberian boreal forests will help us to predict the effects of an increasing number of wildfires, and subsequently forecast the future role of Siberian boreal forests as a carbon sink or source.

The boreal forest biome is composed of a few plant species. In fact, nine tree species belonging to only six genera make up about $95 \%$ of the 500 million ha of Eurasian boreal forest (Wirth et al., 2005). Although it is a scarce number in terms of species, its functional diversity is high since this small assembly of species hosts representatives of four or five distinct plant functional types (PFT) with respect to fire adaptation in trees, namely resisters, avoiders, invaders, and endurers (Rowe, 1983). This functional diversity gives rise to a high diversity of fire regimes ranging from superficial nonlethal surface fires to devastating crown fires (Shvidenko and Nilsson, 2000). 


\section{BACKGROUND}

There is a considerable body of research investigating how warming has and will influence the forests and vegetation of the boreal region, and what the implications of warming in high latitudes are for global-scale carbon dynamics (Goetz et al., 2006). One of the major issues in understanding how climate change will influence carbon storage in boreal ecosystems is accounting for the role of disturbance, including patterns of fire intensity, soil moisture, surface temperature, and vegetation re-growth (Goetz et al., 2006; Harden et al., 2000; French et al., 1996).

The Russian Federal Forest Service reported that between 17,000 and 33,000 forest fires occur each year, affecting up to 2 million ha of forest and other land. Since fires are monitored only on protected forest and pasture lands, there is a strong suspicion that these fire statistics are underestimated. In fact, observations from satellite indicate that during the 1987 fire season approximately 14.5 million ha were burned (Cahoon et al., 1994).

Burn scars and the associated vegetation succession lead to a mosaic of landscape patches that vary in age according to the dates of the fires (Payette, 1992). These spatiotemporal patterns of regenerating vegetation in various successional stages are important considerations for carbon budget studies in the boreal forests. Specifically, the indirect effects on total carbon stored through the influence of fire return interval on stand age distribution, which in turn determines the average biomass/carbon stored in a region (Kasischke and French, 1997) should be investigated.

Several studies have addressed the study of postdisturbance dynamics using remote sensed imagery with different objectives such as (1) studying the relationships between the time elapsed since fire and the recovery stage (Goetz et al., 2006; Hicke et al., 2003; Riaño et al., 2002; DiazDelgado and Pons, 2001; Amiro et al., 2000; Kasischke and French, 1997;Viedma et al., 1997), (2) studying the effects of fire severity on regeneration (Diaz-Delgado et al., 2003; Jakubauskas et al., 1990), (3) quantifying spatial patterns of post-disturbance vegetation (Schroeder and Perera, 2002), (4) mapping successional forest communities (Ustin and Xiao, 2001; Steyaert et al., 1997), or (5) mapping the fractional cover of post-disturbance vegetation layers (Vine and Puech, 1999).

In remote sensing studies, post-fire dynamics analyses have been carried out mostly in Mediterranean ecosystems (e.g. Diaz-Delgado et al., 2003; Riaño et al., 2002; Diaz-Delgado and Pons, 2001; Viedma et al., 1997). There have been only a few attempts to study post-disturbance dynamics in the boreal forest, most of them in North America. Kasischke and French (1997) used a three years AVHRR NDVI record (1990 to 1992) to study 14 test sites in Alaska. They found that factors such as pre-fire vegetation and the timing of the fire during the growing season influence the regrowth of vegetation in Alaskan boreal forests. Amiro et al. (2000) used an NPP map for 1994 to analyse fires occurred between 1980 and 1994 in Canada. They found that NPP increases linearly through the 15 year observation period, at rates that depend on ecoregion. Hicke et al. (2003) assessed the impact of fire on Net Primary Production (NPP), produced using a 17-year time series of
AVHRR NDVI observations together with a vegetation light use efficiency model. These authors estimated a mean post-fire NPP recovery relative to pre-fire values for 61 fire scars in the boreal region of North America in 9 years. Finally, Goetz et al. (2006) used two data sets of AVHRR NDVI (the PathfinderLand and the GIMMS-G) to investigate vegetation recovery after fire in the boreal forest of Canada. They used a 17-year record (1981-1997) but focused their analyses on three episodic years $-1981,1989$, and 1995. Their results indicated that fire disturbance was distinct when compared with unburned areas, and that accounting for the temporal variability of NDVI within unburned areas aided the definition of recovery times to pre-burn levels, which they found to be five years or more.

The use of spectral vegetation indexes is a common element in many of the aforementioned studies, with the NDVI being the most extensively used to assess the regeneration processes after fire.

\section{DATA AND METHODS}

\section{A. Study area}

Our study area is located in Central Siberia, between 52$72^{\circ} \mathrm{N}$ and $88-110^{\circ} \mathrm{E}$. Its 3.2 million $\mathrm{km}^{2}$ area is a mosaic of taiga forest (pine, spruce, fir, larch, cedar, birch and aspen), wetland, open areas and rivers, encompassing some of the economically most valuable forest stands.

\section{B. NDVI time series analysis}

NDVI data at $1 \mathrm{~km}$ pixel size (8-day composites) were calculated from MODIS/Terra $500 \mathrm{~m}$ 8-day composite surface reflectance data for the period 2001-2005.

\section{Fire disturbance map}

The Fire disturbance map (FDM) used here for the period 1992-2003 has been described by Balzter et al. (2005) and George et al. (2006).

\section{Pre-fire forest vegetation classification}

Pre-fire forest vegetation is a factor that has a strong influence on post-fire regeneration (Bonan and Shugart, 1989; Kasischke and French, 1997; Shvidenko and Nilsson, 2000). The IGBP 1992 and GLC2000 land cover maps were used to establish the pre-fire forest type of the burn scars. Burnt areas representing evergreen needle-leaf forests (ENF) and deciduous needle-leaf forests (DNF), the most common forest types of the area, were selected. Post-disturbance dynamics were studied by analysing the selected burned areas (fire scars) in comparison with unburned areas nearby (control plots). Only sites which burned once in the period between 1992 and 2003, were at least $30 \mathrm{~km}^{2}$ in area and did not show an irregular shape were included. This was to reduce the effect of edge pixels which on many occasions are a combination of burned and unburned areas. For each fire scar site an undisturbed adjacent control plot was selected. The distance between the scar and control plot ranged from $2 \mathrm{~km}$ to $9 \mathrm{~km}$. The variation between the fire scars and their controls were interpreted to be solely due to the effect of fire. The period covered by the FDM (1992-2003) and the MODIS NDVI dataset (2001 to 2005) 
allows for an investigation of a chronosequence of fire scars of different age.

\section{RESUlTS}

\section{A. Visual inspectionof the selected burned and control sites}

Due to the special conditions of our data set and the criteria used for the selection it was only possible to assess fires that burned in the years 1992, 1993, 1996, 2002 and 2003. The main constrain was found to be the pre-fire forest type as only burned areas containing more than $80 \%$ of one of the selected forest types were selected. The final number of selected burned areas was 78 (37 for the ENF type and 41 for the DNF type). Visual inspection showed a good match between the boundaries of the FDM burnt areas and the burned areas visible on the MODIS NDVI time series. Visual inspection also showed that the area within burn polygons had varying degrees of burn severity. We decided to include all the pixels within the burned areas to capture most of this variability as opposed to Hicke et al. (2003) who considered only the centroid ("most impacted") pixel within each burned area. We also assessed the adequacy of the selected unburned areas by comparing the prefire values of the burned and unburned areas. The results show a good agreement with an overall $1.45 \%$ difference with respect to unburned, being $1.94 \%$ for the DNF type and $0.96 \%$ for the ENF type.

\section{B. Post-fire NDVI dynamics}

The pairs of burned and unburned control areas were grouped according to the time of burn. The difference between the burned and unburned areas was then calculated to build up a response of the NDVI to disturbance over time, accounting for the influence of inter-annual variability and other environmental factors captured in the unburned areas (Goetz et al., 2006). The difference of mean annual NDVI between burned and unburned areas as a function of time after the fire is represented in Fig. 1 and shows reduced values at the time of

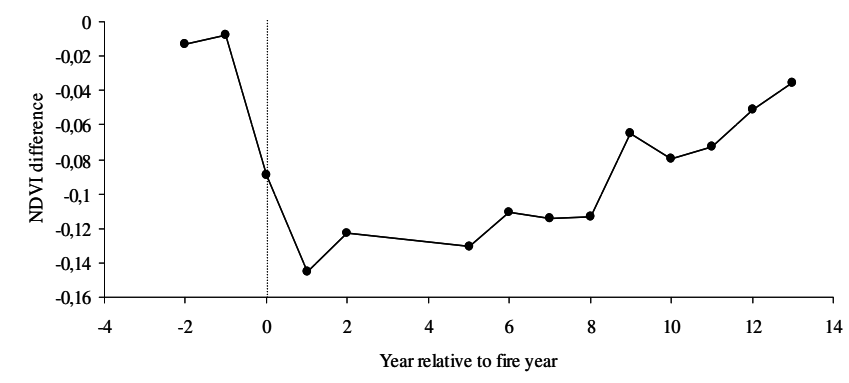

Figure 1. NDVI difference between burned and unburned areas plotted as a function of year relative to fire year.

fire (year 0), followed by a gradual recovery over more than 13 years. A One-Way ANOVA indicated that 13 years after the fire the differences between the burned and unburned areas were still significant $(p=0.001)$ although the NDVI in burned areas was just $5.2 \%$ lower than that in unburned areas. In the pre-fire years the differences between burned and unburned areas were not significant (year $-2, p=0.447$; year $-1, p=$
0.668), which indicates that the control sites were similar in characteristics to the burned areas before the fire.

\section{DISCUSSION}

The recovery rates found here are longer than the 9 years reported by Hicke et al. (2003) for North America or the 5-year recovery period reported by Goetz et al. (2006) for Canada. Goetz et al. (2006) reported that the differences found between their results and those of Hicke et al. (2003) might be associated with the consideration of the entire burned area (Goetz et al., 2006) rather than the most impacted pixel (Hicke et al, 2003), which might need a longer period to regenerate. However, we are also considering the entire burned area so, which raises the question why we obtain a much longer recovery period than Goetz et al. (2006). This question becomes crucial if we bear in mind that the prevailing fire type has been reported to differ markedly in the boreal forests of Siberia and North America. While in Siberia in a typical year some $75 \%$ of the forest area burn in surface fires (Shvidenko and Nilsson, 2000), crown fires which tend to consume more fuel than surface fires dominate in the boreal forest of North America (Kasischke, 2000). Fire radiative power retrievals over Russia and North America showed that Russian fires tended to have lower fire intensity (Wooster and Zhang 2004).

Other factors must also be considered. Goetz et al. (2006) used $8 \mathrm{~km}$ composites while in this study we are using $1 \mathrm{~km}$. Recovery times may be scale-dependent, so nonlinearities in aggregating NDVI over an $8 \mathrm{~km}$ pixel may result in a faster predicted recovery than the actually observed for a smaller, completely burned region (Hicke et al., 2003). If the maximum-NDVI compositing method was used to generate the $8 \mathrm{~km}$ data then the dataset would also show a faster recovery than the original $1 \mathrm{~km}$ data. Goetz et al. (2006) used AVHRR NDVI in contrast to the MODIS NDVI used in this study. The bandwidths and spectral response associated with the red and NIR data used to compute NDVI differ for MODIS and AVHRR sensors. Different capabilities to discriminate between burned and unburned areas could influence the large difference in our results. Forests in Siberia also grow under more extreme climatic conditions than those in North America. The climate of the Siberian boreal forest is colder and drier than Canada. Furthermore, the Siberian boreal forest grows over a much larger area of continuous and discontinuous permafrost (Bonan and Shugart, 1989). Finally, a difference in species composition of the Canadian and Siberian forests is another potential source of variation on regeneration rates. The majority of the Siberian Taiga is dominated by larch (Larix $s p$.), a deciduous conifer, while evergreen conifers (Picea mariana, P. glauca and Pinus banksiana) dominate in the Canadian boreal forest.

\section{CONCLUSION}

A methodological approach to study post-fire NDVI has been proposed here. We employed a 16-years observation period to study two years prior to the fire, the fire year, and thirteen years after the fire. The time series allowed us to explore the depletion and vegetation recovery following fires. By coupling information on burned and unburned areas, we were able to separate inter-annual variations caused by local 
climate from changes in the behaviour due to a burn. Our results indicated that it takes more than 13 years for the NDVI signal to fully recover after fire, although at this time much of the burned areas show values similar to the unburned areas. The results also suggest that variability observed in post-fire NDVI can be explained partially by the dominant forest type. NDVI for the ENF type seems to be more affected by fire than for the DNF type. Next steps will be to resolve some of the remaining uncertainties by introducing climatic data, fire severity and latitude.

\section{REFERENCES}

[1] AMIRO, B.D., CHEN, M., LIU, J., 2000, Net primary productivity following forest fire for Canadian ecoregions. Canadian Journal of Forest Research, 30, 939-947.

[2] BALZTER, H., GERARD, F.F., GEORGE, C.T., ROWLAND, C.S., JUPP, T.E., MCCALLUM, I., SHVIDENKO, A., NILSSON, S., SUKHININ, A., ONUCHIN, A. and SCHMULLIUS, C., 2005, Impact of the Arctic Oscillation pattern on interannual forest fire variability in Central Siberia, Geophysical Research Letters 32, doi:10.1029/2005GL022526

[3] BONAN, G. B., and SHUGART, H.H., 1989, Environmental factors and ecological processes in boreal forests. Annual Review of Ecology and Systematics, 20, 1-28.

[4] CAHOON, D.R., STOCKS, B.J., LEVINE, J.S., WESLEY R.C., and PIERSON, J.M., 1994, Satellite analysis of the severe 1987 forest fires in northern China and southeastern Siberia. Journal of Geophysical Research, 99, NO. D9, 18627-18638.

[5] DIAZ-DELGADO, R., LLORET, F. and PONS, X., 2003, Influence of fire severity on plant regeneration by means of remote sensing imagery. International Journal of Remote Sensing, 24, 1751-1763.

[6] DIAZ-DELGADO, R., and PONS, X., 2001, Spatial patterns of forest fires in Catalonia (NE of Spain) along the period 1975-1995. Analysis of vegetation recovery after fire. Forest ecology and Management, 147, 67-74.

[7] DIXON, R. K., BROWN, S., HOUGHTON, R.A., SOLOMON, A.M., TREXLER, M.C., and WISNIEWSKI, J., 1994, Carbon pools and flux in global forest ecosystems. Science, 263, 185-190.

[8] FRENCH, N. H., KASISCHKE, E.S., JOHNSON, R.D., BOURGEAUCHAVEZ, L.L., FRICK, A.L., and USTIN, S.L., 1996, Using multisensor satellite data to monitor carbon flux in Alaskan boreal forests. In: Biomass Burning and Climate Change, Vol. 2, Biomass Burning in South America, Southeast Asia, and Temperate and Boreal Ecosystems, and the Oil Fires of Kuwait (LEVINE, J.L., Ed.). MIT Press, Cambridge, MA, pp. 808-826.

[9] GEORGE, C., ROWLAND, C., GERARD, F., AND BALZTER, H., 2006, Retrospective mapping of burnt areas in Central Siberia using A Modification of the Normalised Difference Water Index, Remote Sensing of Environment 104, 346-359, doi:10.1016/j.rse.2006.05.015.

[10] GOETZ, S.J., FISKE, G.J., and BUNN, A.G., 2006, Using satellite time-series data sets to analyze fire disturbance and forest recovery across Canada. Remote Sensing of Environment, 101, 352-365.

[11] GOLDAMMER, J. G., and STOCKS, B.J., 2000, Eurasian perspective of fire: dimension, management, policies and scientific requirements. In: Fire, climate change and carbon cycling in the boreal forest (Kasischke, E.S., and Stocks, B.J., Ed.). Ecological studies series, Springer-Verlag, pp. 49-65.

[12] HARDEN, J.W., TRUMBORE, S.E., STOCKS, B.J., HIRSCH, A., GOWER, S.T., O'NEILL, K.P., and KASISCHKE, E.S., 2000, The role of fire in the boreal carbon budget. Global Change Biology, 6 (Suppl. 1), 174-184.

[13] HICKE, J. A., ASNER, G.P., KASISCHKE, E.S., FRENCH, N.H.F., RANDERSON, J.T., COLLATZ, G.J., STOCKS, B.J., TUCKER, C.J., LOS, S.O., and FIELD, C.B., 2003, Postfire response of North American boreal forest net primary productivity analyzed with satellite observations. Global Change Biology, 9(8), 1145-1157.
[14] JAKUBAUSKAS, M. E., LULLA, K.P., and MAUSEL, P.W., 1990, Assessment of vegetation change in a fire-altered forest landscape. Photogrammetric Engineering and Remote Sensing, 56(3), 371-377.

[15] KASISCHKE, E. S., 2000, Boreal ecosystems in the Global Carbon Cycle. In: Fire, climate change and carbon cycling in the boreal forest (Kasischke, E.S., and Stocks, B.J., Ed.). Ecological studies series, Springer-Verlag, pp. 19-30.

[16] KASISCHKE, E. S., and FRENCH, N.H.F., 1997, Constraints on using AVHRR composite index imagery to study patterns of vegetation cover in boreal forests. International Journal of Remote Sensing, 18(11), 2403-2426.

[17] LITVAK, M., MILLER, S., WOFSY, S.C., and GOULDEN, M., 2003, Effect of stand age on whole ecosystem $\mathrm{CO} 2$ exchange in the Canadian boreal forest. Journal of Geophysical Research, 108 (D3), 10.1029/2001JD000854.

[18] PAYETTE, S., 1992, Fire as controlling process in the North American boreal forest. In: A systems analysis of the global boreal forest (SHUGART, H.H., LEEMANS, R., and BONAN, G.B, Ed.). Cambridge, UK, Cambridge University Press, pp. 144-165.

[19] RIAÑO, D., CHUVIECO, E., USTIN, S., ZOMER, R., DENNISON, P., ROBERTS, D. and SALAS, J., 2002, Assessment of vegetation regeneration after fire through multitemporal analysis of AVIRIS images in the Santa Monica Mountains. Remote Sensing of Environment, 79, 60-71.

[20] ROJKOV, V.A., EFREMOV, D., NILSSON, S., SEDYKH, V.N., SHVIDENKO, A.Z., SOKOLOV, V., and WAGNER, V.B., 1996, Siberian landscape classification and a digitized map of Siberian landscapes. WP-96-111. International Institute for Applied Systems Analysis, Laxenburg, Austria. Cited in: SHVIDENKO, A., and NILSSON, S., 2000, Fire and the carbon budget of Russian forests. In: Fire, climate change, and carbon cycling in the Boreal forest (KASISCHKE, E.S., and STOCKS, B.J., Ed.). Springer-Verlag, New York, pp. 289-311.

[21] ROWE, J.S., 1983, Concepts of fire effects on plant individuals and species. In: The role of fire in northern circumpolar ecosystems (Wein, R.W., and McLean, D.A., Ed.). SCOPE. Wiley \& Sons, pp. 135-154.

[22] SCHROEDER, D. and PERERA, A.H., 2002, A comparison of largescale spatial vegetation patterns following clearcuts and fires in Ontario's boreal forests. Forest Ecology and Management, 159(3), 217230.

[23] SHVIDENKO, A., and NILSSON, S., 2000, Extent, distribution, and ecological role of fire in Russian forests. In: Fire, climate change, and carbon cycling in the Boreal forest (Kasischke, E.S., and Stocks, B.J., Ed.). Ecological studies, 138. Springer-Verlag, New York, pp. 132-150.

[24] STEYAERT, L. T., HALL, F.G., and LOVELAND, T.R., 1997, Land cover mapping, fire regeneration, and scaling studies in the Canadian boreal forest with $1 \mathrm{~km}$ AVHRR and Landsat TM data. Journal of Geophysical Research - Atmospheres, 102(D24), 29581-29598.

[25] TRUMBORE, S. E., and HARDEN, J.W., 1997, Accumulation and turnover of carbon in organic and mineral soils of the BOREAS northern study area. Journal of Geophysical Research, 102 (D24), 28817-28830.

[26] USTIN, S. L. and XIAO, Q.F., 2001, Mapping successional boreal forest in interior central Alaska. International Journal of Remote Sensing, 22(6), 1779-1797.

[27] VIEDMA, O., MELIA, J., SEGARRA, D., and GARCIA-HARO, J., 1997, Modelling rates of ecosystem recovery after fires using Landsat TM data. Remote Sensing of Environment, 61, 383-398.

[28] VINE, P., and PUECH, C., 1999, Cartography of post-fire forest regeneration by coupling a spectral mixture model with a vegetation regrowth model. Canadian Journal of Remote Sensing, 25(2), 152-159.

[29] WIRTH, C., 2005, Fire regime and tree diversity in Boreal forests: implication for the carbon cycle. Ecological studies, 176, 309-344.

[30] WOOSTER, M..J and ZHANG, Y.-H. 2004. Boreal Forest Fires Burn Less Intensely in Russia than in North America. Geophysical Research Letters 31: doi:10.1029/2004GL020805O 